\title{
Prevention of perioperative atrial fibrillation with beta blockers in elderly patient during abdominal surgery
}

\author{
Gennaro Pagano ${ }^{1 *}$, Dario Leosco ${ }^{1}$, Nicola Ferrara ${ }^{1,2}$, Nicola Rocco $^{3}$, Corrado Rispoli $^{4}$, Loredana lannone ${ }^{5}$, \\ Serena Testa ${ }^{4}$, Rita Compagna ${ }^{6}$, Antonello Accurso ${ }^{6}$, Bruno Amato ${ }^{6}$
}

From 26th National Congress of the Italian Society of Geriatric Surgery

Naples, Italy. 19-22 June 2013

\section{Aim of the study}

To investigate whether pharmacologic prophylaxis with Beta Blocker Carvedilol reduce perioperative Atrial Fibrillation (AF) in elderly patients during abdominal surgery.

\section{Background}

Peri-operative AF is the consequence of stress activation of Sympathetic Nervous System (SNS) following surgery $[1,2]$. The incidence of AF increase with the aging and in presence of comorbidities [3-5]. Clinical consequences include reduced cardiac output, lengthened hospitalization, an increase in the risk of cerebral thromboembolism and in many cases the need for systemic anticoagulation [6]. SNS overactivation could be treated with Beta Blockers and may reduce the occurrence of AF [7-10].

\section{Methods}

A prospective, randomized, single-blind, controlled pilot study in patients undergoing abdominal surgery (right emicolectomy, sigmoidectomy and anterior rectal resection) was conducted. 22 elderly patients (70 years old and over) were randomized to control (ctr) $(\mathrm{n}=13)$ and Carvedilol (carv) $(\mathrm{n}=9)$ groups. Treatment was received only during and 36 hours after surgery in the carv group.

\section{Results}

The occurrence of AF were 3 in ctr group and in 0 in carv group $(\mathrm{p}<0.0001)$. No statistical differences were

\footnotetext{
* Correspondence: gennaropagano85@hotmail.com

'Department of Translational Medical Sciences, Federico II University of

Naples, Naples, Italy

Full list of author information is available at the end of the article
}

present in demographic and clinical characteristics between two groups. No correlation was found between age and the incidence of AF..

\section{Conclusions}

In the elderly patients underwent abdominal surgery, the reduction of SNS with Beta Blocker Carvedilol should be useful to reduce the occurrence of peri-operative $\mathrm{AF}$ and, consequently, to reduce the impact of AF cardiovascular complications.

\section{Authors' details}

'Department of Translational Medical Sciences, Federico II University of Naples, Naples, Italy. ${ }^{2}$ "Salvatore Maugeri" Foundation, IRCCS Scientific Institute of Telese Terme, Benevento, Italy. ${ }^{3}$ Department of Biomedical, Surgical and Dental Sciences, University of Milan, Milan, Italy. ${ }^{4}$ Department of General Surgery - ASL NA1, Cardinale Ascalesi Hospital, Naples, Italy. ${ }^{5}$ Department of General Surgery, Fatebenefratelli Hospital, Benevento, Italy. ${ }^{6}$ Department of General, Geriatric, Oncologic Surgery and Advanced Technologies, Federico II University of Naples, Naples, Italy.

Published: 16 September 2013

\section{References}

1. Rengo G, Leosco D, Zincarelli C, Marchese M, Corbi G, Liccardo D, Filippelli A, Ferrara N, Lisanti MP, Koch WJ, Lymperopoulos A: Adrenal GRK2 lowering is an underlying mechanism for the beneficial sympathetic effects of exercise training in heart failure. American Journal of Physiology - Heart and Circulatory Physiology 2010, 24(9).

2. Leosco D, Rengo G, laccarino G, Golino L, Marchese M, Fortunato F, Zincarelli C, Sanzari E, Ciccarelli M, Galasso G, Altobelli GG, Conti V, Matrone G, Cimini V, Ferrara N, Filippelli A, Koch WJ, Rengo F: Exercise promotes angiogenesis and improves $\beta$-adrenergic receptor signalling in the post-ischaemic failing rat heart. Cardiovascular Research 2008, 30(3).

3. Rengo F, Parisi V, Rengo G, Femminella GD, Rengo C, Zincarelli C, Pagano G, Festa G, De Lucia C, Leosco D: Instruments for geriatric assessment: new multidimensional assessment approaches. JOURNAL OF NEPHROLOGY 2012, 25:73-78, ISSN: 1121-8428, do: 10.5301/jn.5000164.

4. Pilotto A, Addante F, Franceschi M, Leandro G, Rengo G, D'Ambrosio P, Longo MG, Rengo F, Pellegrini F, Dallapiccola B, Ferrucci L: A Multidimensional Prognostic Index (MPI) based on a Comprehensive 
Geriatric Assessment Predicts Short-Term Mortality in Older Patients with Heart Failure. Circulation: Heart Failiure 2010, 3:14-20.

5. Rispoli C, Rocco N, lannone L, Amato B: Developing guidelines in geriatric surgery: role of the grade system. BMC Geriatrics 2009, 9(SUPPL.1):A99.

6. Rengo G, Pagano G, Squizzato A, Moja L, Femminella GD, de Lucia C, Komici K, Parisi V, Savarese G, Ferrara N, Perrone-Filardi P, Leosco D: Oral anticoagulation therapy in heart failure patients in sinus rhythm: a systematic review and meta-analysis. PloS One 2013, 8(1):e52952, doi:10.1371/journal.pone.0052952.

7. Paolillo S, Rengo G, Pagano G, Pellegrino T, Savarese G, Femminella GD, Tuccillo, Boemio A, Attena E, Formisano R, Petraglia L, Scopacasa F,

Galasso G, Leosco D, Trimarco B, Cuocolo A, Perrone-Filardi P: Impact of Diabetes Mellitus on Cardiac Sympathetic Innervation in Patients With Heart Failure. A lodine-123 meta-iodobenzylguanidine (I123MIBG) Scintigraphic Study. Diabetes Care 2013.

8. Rengo G, Lymperopoulos A, Zincarelli C, Femminella Gd, Liccardo D, Pagano G, de Lucia C, Cannavo A, Gargiulo P, Ferrara N, Perrone Filardi P, Koch Wj, Leosco D: Blockade of beta-adrenoceptors restores the GRK2mediated adrenal alpha(2) -adrenoceptor-catecholamine production axis in heart failure. BRITISH JOURNAL OF PHARMACOLOGY 2012, 166:2430-2440, ISSN: 1476-5381, doi: 10.1111/j.1476-5381.2012.01972.x.

9. Rengo G, Zincarelli C, Femminella GD, Liccardo D, Pagano G, de Lucia C, Altobelli GG, Cimini V, Ruggiero D, Perrone-Filardi P, Gao E, Ferrara N, Lymperopoulos A, Koch WJ, Leosco D: Myocardial beta(2) -adrenoceptor gene delivery promotes coordinated cardiac adaptive remodelling and angiogenesis in heart failure. BRITISH JOURNAL OF PHARMACOLOGY 2012, 166:2348-2361, ISSN: 1476-5381, doi: 10.1111/j.1476-5381.2012.01954.x.

10. Rengo G, Perrone-Filardi $P$, Femminella GD, Liccardo $D$, Zincarelli $C$, de Lucia C, Pagano G, Marsico F, Lymperopoulos A, Leosco D: Targeting the beta-adrenergic receptor system through $\mathrm{G}$-protein-coupled receptor kinase 2: a new paradigm for therapy and prognostic evaluation in heart failure: from bench to bedside. CIRCULATION. HEART FAILURE 2012, 5:385-391, ISSN: 1941-3289, doi: 10.1161/CIRCHEARTFAILURE.112.966895.

doi:10.1186/1471-2482-13-S1-A34

Cite this article as: Pagano et al:: Prevention of perioperative atrial fibrillation with beta blockers in elderly patient during abdominal surgery. BMC Surgery 2013 13(Suppl 1):A34.

\section{Submit your next manuscript to BioMed Central and take full advantage of:}

- Convenient online submission

- Thorough peer review

- No space constraints or color figure charges

- Immediate publication on acceptance

- Inclusion in PubMed, CAS, Scopus and Google Scholar

- Research which is freely available for redistribution

Submit your manuscript at www.biomedcentral.com/submit
Biomed Central 